[2] Калмыкова, И.С., Ковалева, И.А., Герус, Л.В., Федоренко, М.Г. (2014) Технологическая оценка винограда сорта Шкода и выбор направления его использования . Пищевая наука и технология, 3(28), 62-67.

[3] Сахаров, В. И., Сахарова, С.В. (2014) Экономичный Ethernet доступ на микроконтроллере. Наукові праці ДонНТУ, 2 (27), 80-85.

[4] Сахаров, В.И. (2013) Использование локальной сети для контроля температуры и влажности воздуха. Холодильна техніка і технологія, 3(143), 80.

[5] Сахаров, B.I. (2010) Віртуальні технології навчання. Застосування повноекранного програмного стимулятора ACS51 фірми Фітон для лабораторних робіт з дисципліни «Мікроконтролерні системи». Збірник наукових праць VI Всеукраїнської науково-методичної конференції, 85.

[6] Сахаров, В. И., Сахарова, С.В. (2014) Использование встроенного ТСР/ІР стека для передачи информации через GPRS. Збірник наукових праць Дон. інститут залізничного транспорту Укр. держ. академії залізничного транспорту, 37, 41-47.

\title{
References
}

[1] Kalmykova, I.S. (2011) Tekhnolohyya vynohradnoho soka s povyshennym soderzhanyem antotsyanov. Kharchova nauka i tekhnolohiya, vol. 3(16), pp. 11-13.

[2] Kalmykova, I.S., Kovaleva, I.A., Gerus, L.V., Fedorenko, M.G. (2014) Tekhnologicheskaya otsenka vinograda sorta Shkoda i vybor napravleniya yego ispol'zovaniya . Pishchevaya nauka i tekhnologiya, vol. 3(28), pp. 62-67.

[3] Sakharov, V. I., Sakharova, S.V. (2014) Ekonomichnyy Ethernet dostup na mikrokontroleri. Naukovi pratsi DonNTU, vol. 2 (27), pp. 80-85.

[4] Sakharov, V. I. (2013) Yspol'zovanye lokal'noy sety dlya kontrolya temperatury y vlazhnosty vozdukha. Kholodyl'na tekhnika i tekhnolohiya, vol. 3(143), p. 80.

[5] Sakharov, V. I. (2010) Virtual'ni tekhnolohiyi navchannya. Zastosuvannya povnoekrannoho prohramnoho stymulyatora ACS-51 firmy Fiton dlya laboratornykh robit z dystsypliny «Mikrokontrolerni systemy». Zbirnyk naukovykh prats' VI Vseukrayins'koyi naukovo-metodychnoyi konferentsiyi, p. 85.

[6] Sakharov, V. I., Sakharova, S.V. (2014) Yspol'zovanye vstroennoho TCP/IP steka dlya peredachy ynformatsyy cherez GPRS. Zbirnyk naukovykh prats' Don. instytut zaliznychnoho transportu Ukr. derzh. akademiyi zaliznychnoho transportu, vol. 37, pp. 41-47.

УДК 681.3.06

\section{ВИКОРИСТАННЯ СУЧАСНИХ ТЕХНОЛОГІЙ У ВИКЛАДАННІ ТЕХНІЧНИХ ДИСЦИПЛІН}

\author{
Т. М. Моспан ${ }^{1}$, Е. В. Савьолова ${ }^{2}$, В. Я. Ярмолович ${ }^{3}$, С. М. Огінська ${ }^{4}$ \\ 1,3,4Одеський національний політехнічний університет, місце Одеса \\ ${ }^{2}$ Одеська національна академія харчових технологій, місце Одеса \\ ORCID ID: ${ }^{2} 0000-0001-9266-9323,{ }^{3} 0000-0002-0708-2972,{ }^{4} 0000-0002-7542-8760$ \\ E.mails: ${ }^{1}$ Mospan@opu.ua, ${ }^{2}$ elvira.onaxt@gmail.com, ${ }^{3}$ vyy0147@gmail.com, ${ }^{4}$ osn308@ gmail.com
}

Copyright (C) 2018 by author and the journal "Automation technologies and business - processes. This work is licensed under the Creative Commons Attribution International License (CC BY). http://creativecommons.org/licanses/by/4.0

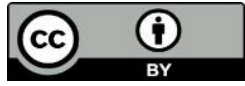

ONAFT

Open Access

DOI: 10.15673/atbp.v10i1.874

Анотація. Динаміка розвитку сучасного суспільства ставить перед викладачем непросте завдання викладу навчального матеріалу таким чином, щчоб студенти за короткі терміни могли засвоювати максимально можливу кількість знань разом з набуттям навичок їх творчого застосування на практиці. 
Процес навчання - цее завжди процес взаємодії двох сторін: викладача, щуо надає інформацію, і студентів, які ї̈ отримують. Саме якість изєї взаємодії, вміння викладача знайти підхід до кожного в групі $і$ в зрозумілій, доступній формі викласти складний матеріал виробляє у студента почуття впевненості в своїх силах, навички активізації розумової діяльності для вирішення нестандартних завдань, визначає успішність майбутнього фахівия. Тому мета иієї статті - показати на власному педагогічному досвіді важливість живого спілкування педагога зі студентом в будь-яких формах навчання, включаючи $і$ дистанційне, необхідність використання інтуїтивного, асоиіативного $i$ логічного мислення, як інструментів навчання.

Впровадження педагогічних інновачій у учбовій процес полягає в новому баченні методологї̈ навчання, залучення мультимедійних засобів навчання при викладанні нового матеріалу, грамотного поєднання нового з уже перевіреним роками на практиці старим.

Abstract. The dynamics of the development of modern society confronts the teacher with the difficult task of presenting the teaching material in such a way that students can acquire as much knowledge as possible in a short period of time, together with the acquisition of skills for their creative application in practice.

The process of education is always a process of interaction between the two sides: the teacher giving information, and the students receiving it. It is the quality of this interaction, the ability of the teacher to find an approach to everyone in the group and in an understandable, accessible form to present complex material, develops a student's sense of self-reliance, the skills of activating thought activity for solving non-standard problems, and determines the success of a future specialist. Therefore, the purpose of this article is to show on the own teaching experience the importance of a live communication between a teacher and a student in all forms of learning, including distance, necessity for intuitive, associative and logical thinking as a learning tool.

Therefore, the meaning and purpose of pedagogical innovations lies in a new vision of the methodology of teaching, the attraction of multimedia teaching aids in the presentation of new material, the competent combination of the new with the already proven years in practice, the old.

Ключові слова: педагогічні інновації, сучасні технологї, процес навчання, інтуїтивне мислення, асоиіативне та логічне мислення, мотивація.

Key words: pedagogical innovations, modern technologies, educational process, intuitive thinking, associative and logical thinking, motivation.

Ми живемо в епоху науково-технічного прогресу, і вища освіта, як і все наше суспільство, знаходиться в стані постійних змін. Здійснено входження вітчизняних ВНЗ до Болонського процесу, широко використовуються нові інноваційні методи навчання, впроваджується система дистанційного навчання. I вже зараз можна бачити переваги і недоліки деяких нововведень. На сьогоднішній момент, найбільш затребувані фахівці інженерних професій, а особливо фахівці, які вміють нестандартно мислити, творчо підходити до вирішення різних завдань.

Тому завданням будь-якого вищого навчального закладу є створення «людини у постійному розвитку»[1]: не тільки випуск висококваліфікованого фахівця, але і залучення студентів до розробки принципово нових технологій вже в процесі навчання, прищеплення навичок адаптації до реальних умов виробничого середовища і мінливим потребам ринку.

Процес навчання - це завжди процес взаємодії двох сторін: викладача, що дає інформацію, і студентів, які іiі отримують. Саме від якості цієї взаємодії, від уміння викладача знайти підхід до кожного в групі і в зрозумілій, доступній формі викласти часом дуже складний матеріал залежить:

- зацікавленість студента у вивченні дисципліни і самоосвіті;

- формування у студента власної точки зору по питанню, що викладається і вміння ії відстоювати;

- ефективне засвоєння матеріалу;

- самостійність в пошуку алгоритму вирішення поставленого завдання;

- вміння аргументовано і грамотно пояснити правильність прийнятого рішення;

- вироблення навичок роботи в команді; тобто всього того, що визначає усвідомлену компетентність і успішність майбутнього фахівця.

Придбання перерахованих вище навичок багато в чому залежить від змісту і методики навчання. Тому сенс і мета педагогічних інновацій полягає в новому баченні методології навчання, залучення мультимедійних засобів навчання при викладанні нового матеріалу, грамотного поєднання нового з уже перевіреним роками на практиці старим. Хороша програма навчання повинна бути націлена на повне залучення і занурення студентів в освітній процес і подальшу самоосвіту. Курс освіти не повинен вселяти в студентів почуття роз'єднаності, самотності або ізоляції. Програма повинна включати методи і прийоми для створення атмосфери присутності, співпраці.

У зв'язку з цим завдання вищої школи бачиться не тільки в тому, щоб дати студентові певний набір знань, але і в тому, щоб навчити студента навчатися, активувати розумову діяльність, з використанням інтуїтивного, асоціативного і логічного мислення знаходити нові нетипові шляхи вирішення практичних завдань, то б то навчити працювати, навчити співіснувати, навчити жити. 
http://www.atbp.onaft.edu.ua/

\section{Ціль роботи}

Показати на власному педагогічному досвіді важливість живого спілкування педагога зі студентом в будь-яких формах навчання, включаючи і дистанційне, необхідність використання інтуїтивного, асоціативного і логічного мислення, як інструментів навчання, активного впровадження інформаційно-комунікаційних технологій (ІКТ) для підвищення ступеня розумової активності та пробудження у студентів інтересу до самої навчально-пізнавальної діяльності, а внаслідок цього удосконалення учбового процесу з підготовки спеціалістів в галузі автоматизації.

\section{Матеріали досліджень}

Починаючи вивчати новий предмет, студент має певні знання: побутові, почерпнуті з науково-популярної літератури, життєвого досвіду. Читаючи лекцію, нам необхідно спиратися на ці знання. Використовуючи терміни, давати їх переклад, пояснювати їх походження. Наприклад, гістерезис походить від слова Histori, тобто в цьому явищі важлива передісторія об'єкта.

Професор Атанов Г.А. в своій роботі «Обучение и искусственный интеллект или основы современной дидактики высшей школы» пише, що матеріал бажано викласти так, щоб студент не відчував ущербності від своєї психологічної та дидактичної непідготовленості, по можливості не плести мережива 3 наукових термінів. Науковість при такому підході анітрохи не страждає, навпаки, такий підхід дозволяє досягати більш високого ступеня узагальнення. Це є запорукою модернізації навчання[2].

Лекція, прочитана викладачем повинна відрізнятися від глави у підручнику наявністю прикладів, які враховують «життєвий досвід» слухачів, зрозуміло пояснюють досліджуване явище. Це дозволяє підключити їх інтуїтивне і асоціативне мислення. Наприклад, гістерезис - це запізнювання реакції об'єкта на вплив, залежне від попереднього стану об'єкта. Розрізняють механічний, електричний, магнітний ... і «інтелектуальний гістерезис». «Інтелектуальний гістерезис» - це запізнювання реакції студента на вплив в процесі навчання, залежне від того, чи піддавався він процесу навчання раніше або піддається йому вперше. Як правило, цей приклад викликає у студентів посмішку розуміння. Ще приклад - розрізняють динамічну і кінетичну в'язкості рідини. Кінетична - характеризує швидкість розтікання калюжі сметани на столі, а динамічна - кількість води, яку встигнеш донести в панамці 3 моря до спини товариша. Вважаємо, такі приклади викликають у студентів певні асоціації, які не тільки допоможуть зрозуміти матеріал, але і при необхідності його згадати[3].

Інновації - це цілеспрямовані зміни, що вносять в освіту нові елементи, і викликають його удосконалення, це живий організм, система, яка зазнає постійного розвитку[4]. В даний час ми широко використовуємо при читанні лекцій та проведенні практичних і лабораторних робіт 3 програмування в об'єктно-орієнтованих середовищах інтерактивні засоби. Наприклад, при проведенні лабораторної роботи весь процес програмування відображається на інтерактивній дошці, і всі студенти залучені в процес, який контролюється викладачем. Це дає можливість наочно аналізувати отримані результати, обговорювати і усувати помилки, що виникають. Тим самим формується командний дух. Інтерактивні засоби дозволяють представити об'єкт дослідження в будь-якому ракурсі, ознайомити 3 новітніми досягненнями у галузі науково-технічних розробок.

Непогано було б навчити студентів розрізняти причинно-наслідкові явища. Часто доводиться чути від студентів, що втрати в діелектрику виникають внаслідок його нагрівання, а не навпаки, нагрів діелектрика обумовлений діелектричними втратами, що виникають в діелектрику під дією електричного поля. Викладаючи суто теоретичні предмети, наприклад, такі як «теоретичні основи електротехніки», дуже важливо показувати їх взаємозв'язок з іншими дисциплінами. Практично, в кожній темі є можливість посилатися і застосовувати знання з обчислювальної техніки, електротехнічних матеріалів, основ метрології та електротехнічних вимірювань, електричних машин і т. i.

Вивчаючи будь-яке явище, студент повинен навчитися розбивати його на прості елементи і вибудовувати логічні послідовності. Це дозволить створювати хороші алгоритми, а значить хороші програми, що описують певний процес, розбивати ціле на дрібні деталі, описати кожен елемент i, зібравши, знову отримати ціле. Тут особливо важлива здатність логічного мислення. Інтуїція, життєвий досвід, логіка дозволяють раціонально комбінувати блоки програм. Так принцип дії машини постійного струму (МПС), який і у генераторному, і у двигунному режимах роботи визначається двома основними величинами: ЕРС (Е), що індуктується в обмотці якоря, та обертальним електромагнітним моментом (МоБ), який виникає в якорі, можливо представити в вигляді спрощеної блок-схеми (рис. 1), яка просто запам’ятовується и логічно пояснює послідовність походження електромагнітних явищ.

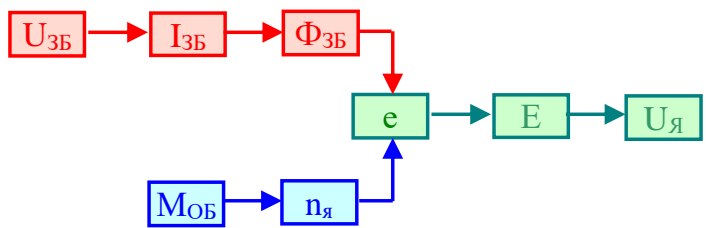

a)

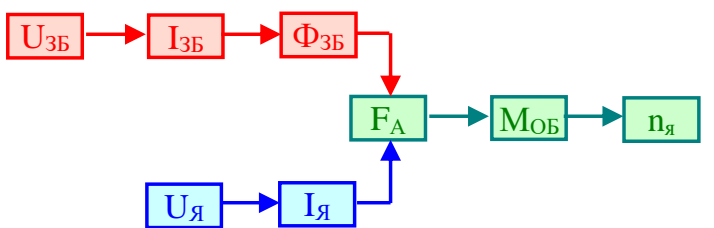

б)

Рис. 1 - Блок-схема принципу дії МПС у генераторному (а) та двигунному (б) режимах 
Як казав Аристотель: «Щоб вивчити - треба впорядкувати». Будь-яке явище ми можемо розглядати з урахуванням причинно-наслідкових зв'язків, грамотно використовуючи математичний апарат, описати його по блоках, попередньо поставивши логічну послідовність подій і процесів. Наприклад, розглянемо вплив температури на питомий опір металів. Зі збільшенням температури $(\mathrm{t})$ збільшується амплітуда коливань вузлів кристалічної решітки $(\Delta)$, це веде до зменшення довжини вільного пробігу електронів $(\lambda)$, що зменшує електропровідність металів $(\gamma)$, тобто питомий опір металів ( $\rho)$ зі збільшенням температури збільшується. Отримуємо ланцюжок: $\mathrm{t} \uparrow \Delta \uparrow \lambda \downarrow \gamma \downarrow \rho \uparrow$.

Мотивація для студента при навчанні - отримання знань для подальшої професійної діяльності. На наш погляд, не менш важливо - не дати зачахнути інтелекту [5]. Студенту, який підглядає до сусіда, можна сказати: «Якщо ви хочете накачати біцепс, ви ж не попросите товариша сходити на тренажери? Сіру речовину теж треба качати - інакше відімре за непотрібністю ». Зараз спостерігається деяке «обожнювання» обчислювальної техніки. Коли студенту потрібно розділити 1 на 0,2 він хапається за калькулятор. Але ж арифметика - це зарядка для «сірої м'язи». Вирішивши завдання за допомогою комп'ютера і отримавши неправильний результат, він виправдовується «таке рішення видав комп'ютер». Переконуєш студента, що комп'ютер лише виконав ті дії, які запрограмовані користувачем. А він зі своїм інтелектом повинен був передбачити правильний результат, тобто результат повинен бути очікуваним. Якщо ви знаєте, що відносна діелектрична проникність речовини не може бути менше одиниці, а результат вийшов рівним 0,5 , то шукайте помилку в обчисленнях. Хорошою розминкою для «сірої м'язи» може бути екстенсивне тестування, коли велику кількість простих завдань студент повинен виконати за певний час, отже, у нього немає часу для використання обчислювальної техніки. У цьому випадку студент змушений підключати інтуїтивне, асоціативне, логічне мислення, а також використовувати свій «жорсткий диск» для вилучення раніше накопиченої інформації, життєвого досвіду.

Навчаючи, можливо, не треба змушувати студентів весь час «винаходити велосипед». Якщо є простий швидкий спосіб досягнення мети, вирішення питання, його треба показати. Тоді, можливо, виникнуть нові алхіміки, які, побачивши простоту теорії Аристотеля, кинулися шукати філософський камінь, щоб прискорити процес «дозрівання простих металів» і отримання золота, заклавши при цьому основи науки хімії. 3 іншого боку треба давати можливість, стимул для творчого пошуку[6]. У Дені Дідро є хороша фраза: «Людина не робить нічого, якщо немає мети, і не робить нічого великого, якщо мета жалюгідна»[7]. Тобто цікавий курс повинен спонукати творче начало студента.

Інтелект - одна з найважливіших характеристик особистості. Він проявляється в пізнавальній та творчій діяльності, включає процес придбання знань, здатність до навчання, самонавчання і самовиховання. В процесі самонавчання головне безперервність, особливо в наш час інтенсивного потоку нового. Факторами, що спонукають до самоосвіти, можуть бути: мотивація, доступність викладання, наочні приклади застосування отриманих знань. I все це входить в завдання викладача. «Docendo discimus» той хто вчить - вчиться, як казали древні [8].

Таким чином, на завершення хочеться сказати, що найкращий результат може бути отриманий тільки при ефективному поєднанні інноваційних та людських ресурсів: молоток - продовження руки, керованої мозком. Від міцності цього взаємозв'язку, іiі гнучкості та взаємопроникнення залежить результат впровадження інноваційних процесів в життя. П'ятирічний син однієї з авторів запитав: «Сонце світить - трава росте, корова їсть траву, ми їмо корову ... а ми навіщо?» Невже в цьому еволюційному колі ми для того, щоб створити біороботів і злитися 3 ними? Викладачеві впору починати лекцію молитвою: «Господи, дай їм благодать вчення, щоб вони могли зростати над собою». Ми працюємо з Ноmо Sapiens і наше головне завдання, полягає в тому, щоб він не припинив бути мислячим.

\section{Висновки}

Аналіз вищевикладеного дає нам можливість рекомендувати використання при стаціонарному навчанні елементів дистанційного. I при створенні нових дистанційних курсів з вивчення технічних дисциплін: теорії електричних сигналів та кіл, метрологія та основи вимірювань, електротехнічних матеріалів, теоретичних основ електротехніки передбачати змішану систему, в якої є наявність діалогу викладач - студент.

\section{Список використаних джерел}

[1] Дичківська I. М. Інноваційні педагогічні технології [Текст] / I. М. Дичківська. - Кіїв: Академвидав, - 2015. - 304 c.

[2] Атанов, Г.А. Обучение и искусственный интеллект, или Основы современной дидактики высшей школы [Текст] / Г.А. Атанов, И.Н. Пустынникова. - Донецк : Изд-во ДОУ, - 2002. - 504 с.

[3] Атанов. Г.А. Деятельностный подход в обучении [Текст] / Г.А. Атанов. - Донецк : ЕАИ-прес, - 2001. - 180 с.

[4] Зудина Е.В. Педагогическая инноватика в управлении персоналом образовательной организации: задачи и варианты использования [Текст] / Е.В. Зудина // Электронный научно-образовательный журнал ВГСПУ «Грани познания». - 2016. - № 2 (45). - С. 8 - 15

[5] Шляхи реалізації кредитно-модульної системи організації навчального процессу і тестових форм контролю знань студентів - матеріали науково-методичного семінару, Випуск 5 Організація та стандартизація навчального процесу - Одеса : вид-во «Астропринт», 2011. - 111 с.

[6] Юридична енциклопедія: в 6 т. / НАН України; Ін-т держ. і права ім. В. М. Корецького; Гол. ред. Ю. С. Шемшученко. - К.: Юридична думка, 2011. — Т. 1: А-Г. — С. 142-143. 
[7] Філософський енциклопедичний словник : энциклопедия [Текст] / НАН України, Ін-т філософії ім. Г. С. Сковороди ; голов. ред. В. І. Шинкарук. - Київ : Абрис, 2002. - 742 с.

[8] Гринів О. І. Філософія: курс лекцій для аспірантів / О. І. Гринів. - Львів : Тріада плюс, 2016. - 364 с.

\title{
References
}

[1] Dychkivska, I. M. Innovatsiini pedahohichni tekhnolohii [Innovative pedagogical technologies] (2015), Akademvydav, Kiev, 304 p (In Ukrainian).

[2] Atanov, G.A., Pustynnikova I.N. Obuchenie i iskusstvennyy intellekt, ili Osnovy sovremennoy didaktiki vysshey shkoly [Training and Artificial Intelligence, or Basics of Modern Higher School Didactics] (2002), Izd-vo DOU, Donetsk, 504 p (In Russian).

[3] Atanov., G.A. Deyatel'nostnyy podhod v obuchenii [Activity approach in training] (2001), EAI-pres, Donetsk , $180 \mathrm{p}$ (In Russian).

[4] Zudina E.V. Pedagogicheskaya innovatika v upravlenii personalom obrazovatel'noy organizacii: zadachi i varianty ispol'zovaniya [Pedagogical Innovation in Personnel Management of an Educational Organization: Tasks and Uses] (2016), Elektronnyy nauchno-obrazovatel'nyy zhurnal VGSPU «Grani poznaniya», № 2 (45), pp. 8 - 15(In Russian).

[5] Shliakhy realizatsii kredytno-modulnoi systemy orhanizatsii navchalnoho protsessu i testovykh form kontro-liu znan studentiv - materialy naukovo-metodychnoho seminaru [Ways of realization of credit-module system of organization of educational process and test forms of student knowledge control - materials of scientific and methodical workshop] (2011) Orhanizatsiia ta standartyzatsiia navcha-lnoho protsesu ,vyd-vo «Astroprynt», Odesa, Vol.5,111 p.

[6] Shemshuchenko, Yu. S. Yurydychna entsyklopediia: v 6 t.[ Law Encyclopedia: 6 tons.] (2011),NAN Ukrainy; In-t derzh. i prava im. V. M. Koretskoho, Yurydychna dumka,. T. 1: A-H. , pp. 142-143(In Ukrainian).

[7] Shynkaruk , V. I. Filosofskyi entsyklopedychnyi slovnyk : antsyklopedyia [Philosophical Encyclopedia Dictionary: Encyclopedia] (2002), NAN Ukrainy, In-t filosofii im. H. S. Skovorody, Abrys, Kiev, 742 p (In Ukrainian).

[8] Hryniv, O. I. Filosofiia: kurs lektsii dlia aspirantiv [Philosophy: Lectures course for graduate students] (2016), Triada plius, Lviv, 364 p (In Ukrainian).

\section{IMPLEMENTATION OF A STANDARDIZED INFORMATION MANAGEMENT SYSTEM INTO ACTIVITY OF SCIENTIFIC AND TECHNICAL LIBRARY}

\author{
A.Bohdanov' ${ }^{1}$, V.M. Plotnikov' ${ }^{2}$ K.V. Smirnova ${ }^{3}$, I. I.Zinchenko ${ }^{4}$ \\ 1,2,3,4 Odessa National Academy of Food Technologies, Odessa, Ukraine \\ ORCID: ${ }^{20000-0001-9000-2568, ~}{ }^{3} 0000-0002-3818-8083$, \\ E-mail: ${ }^{1}$ bohdanov.artem97@gmail.com, ${ }^{2}$ vmplotnik@gmail.com, ${ }^{3}$ smirnova.kathrin@gmail.com, \\ ${ }^{4}$ libonaft@gmail.com
}

Copyright $(\mathcal{C} 2018$ by author and the journal "Automation technologies and business - processes.

This work is licensed under the Creative Commons Attribution International License (CC BY).

http://creativecommons.org/licanses/by/4.0

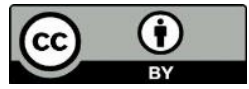

ONAFT

Open Access

DOI: 10.15673/atbp.v10i1.874

An effective solution to the tasks of preserving and accessing electronic documentation requires software applications, namely an electronic archive within the information management system of the organization. The information management system is a digital object-control and management system, as well as facilitates the planning and control functions of the 